\author{
Vaishali D. Naphade ${ }^{1 *}$, Gaurav Parihar $^{1}$, D.K. Jain ${ }^{1}$, Atul R. Bendale ${ }^{2}$ \\ ${ }^{I}$ College of Pharmacy, IPS Academy, Indore, India; \\ ${ }^{2}$ Sandip Institute of Pharmaceutical Sciences, Nashik, Maharashtra \\ *Corresponding author: vaishalinaphade587@gmail.com
}

\title{
Investigation of the effect of agomelatine on cellular and humoral immunity in mice
}

\begin{abstract}
Agomelatine has primarily been described as an antidepressant drug for laborartory animals. In the present study, agomelatine showed an overall stimulatory effect on the specific, as well as on non-specific immune functions of mice. Stimulatory effects were observed at $25 \mathrm{mg} / \mathrm{kg}$. Administration of agomelatine in human beings is simple as it is available in the dosage form. The general immunomodulatory effects of agomelatine need further investigation for its use in the cases of clinical immunostimulation and in order to understand the precise mechanism of action for the stimulatory effect of the drug. The present result suggests that agomelatine may stimulate both the cellular and humoral immunity. Effects were evaluated at different doses of 1, 5 and $25 \mathrm{mg} / \mathrm{kg}$ using various parameters such as effect on hematological parameters. The results were further utilized to evaluate the activity on the cellular and humoral branches of immunity.
\end{abstract}

Keywords: agomelatine, cellular immunity, humoral immunity, immunostimulation, antidepressant, hematology, 5HT2 antagonist, neutrophil adhesion test.

\section{Introduction}

The search for new antidepressants has led to the discovery and development of the agomelatine (Valdoxan). In February, 2009, the agomelatine, a novel antidepressant with an innovative pharmacological profile, had received a marketing authorization by European Medicines Agency for the treatment of major depressive disorders [1-3]. The novel melatonergic agonist/5HT2 antagonist agomelatine displays robust antidepressant properties [4]. Agomelatine is a potent melatonin receptor agonist drug that strongly binds to and stimulates the activity of melatonin MT1 and MT2 receptors which are localized within the SCN [5]. Agomelatine has also been reported to resynchronize circadian rhythms and has anxiolytic properties in animal models. Besides its antidepressant efficacy, it may be helpful in sleep promotion. Agomelatine is an acetamide naphthalene analog of melatonin [2]. Melatonin plays a major role in the regulation of body temperature and consolidation of sleep. Melatonin is involved in the regulation of both cellular and humoral immune responses [6]. Immunological parameters included humoral and cell-mediated immune responses to sheep red blood cells (SRBC) and TLC, DLC.

\section{Materials and Methods}

\section{Animals}

Inbred Swiss albino mice (6-8 weeks) of either sex, weighing about 18-20 g, born and reared in the animal house of College of Pharmacy, IPS Academy, Indore, M.P. from a stock originally purchased from Govt. Veterinary College, MHOW, M.P., were used for the study. Animals were placed randomly in polypropylene cages (five/cage) with husk as bedding. Standard laboratory condition of temperature $25 \pm 2{ }^{\circ} \mathrm{C}$, relative humidity $55 \pm 5 \%$, and $12 \mathrm{~h} / 12 \mathrm{~h}$ light/dark cycle were maintained throughout the experiment. Animals were kept for 1 week to acclimatize to laboratory conditions before starting the experiment; they were given free access to water and standard mice food except during experimentation.

\section{Drug Solution}

Agomelatine - a melatonin receptor agonist, (Sigma Aldrich, USA) was dissolved in hydroxyethylcellulose $1 \%$, and melatonin, N-acetyl-5-methoxytryptamine, (Aristo Pharma, Daman, India) was dissolved in ethanol. The employed doses of agomelatine $(1 \mathrm{mg} / \mathrm{kg}, 5 \mathrm{mg} / \mathrm{kg}, 25 \mathrm{mg} / \mathrm{kg}$, i.p.) and melatonin $(20 \mathrm{mg} / \mathrm{kg}$, $40 \mathrm{mg} / \mathrm{kg}, 60 \mathrm{mg} / \mathrm{kg}$, i.p.) were selected on the basis of our preliminary investigations and previous reports. Normal saline was applied as vehicle. All other chemicals were of analytical grade. 


\section{Experimental design}

\section{Grouping}

Using Swiss albino mice of either sex, 7 groups were formed for the experiments $(n=5)$ fashioned as: Group I: control, normal saline; Group II: $20 \mathrm{mg} / \mathrm{kg}$, MLT i.p.; Group III: $40 \mathrm{mg} / \mathrm{kg}$, MLT, i.p.; Group IV: $60 \mathrm{mg} / \mathrm{kg}$ MLT, i.p.; Group V: $1 \mathrm{mg} / \mathrm{kg}$, AGO, i.p.; Group VI: $5 \mathrm{mg} / \mathrm{kg}$ AGO, i.p.; Group VII: $25 \mathrm{mg} / \mathrm{kg}$ AGO, i.p.

\section{Treatments}

\section{Determination of agomelatine effect on hematological parameters}

Groups I-VII were pre-treated with saline and drug (Ago and Mlt) for 7 days, respectively. At the end of treatment, schedule blood was collected from retro-orbital puncture and parameters such as total RBC count, total WBC count, hemoglobin conten, and was counted with automatic blood cell counter. Differential count (Leishman's stain), were recorded [7, 8].

\section{Assessment of cellular immune functions}

\section{Neutrophil adhesion test}

Swiss albino mice in Groups I-VII were administered by Ago and Mlt and saline for 14 days in their respective groups. Adhesion of neutrophil to nylon fibers was determined using a modification of adherence assay. Briefly, $1 \mathrm{cc}$ tuberculin syringe was uniformly packed with $65 \mathrm{mg}$ to a volume of $0.4 \mathrm{cc}$. This assemble was pre-warmed to $37^{\circ} \mathrm{C}$ in an incubator. Blood samples were collected from mice (after 14 days of drug treatment) by retro-orbital puncture and $1 \mathrm{~mL}$ added to tuberculin syringe and allowed to flow through the fibers for $2 \mathrm{~min}$ with the effluent collected in a test tube. Percent of neutrophil adherence was calculated based on cell counts performed before and after blood sample was passed through the syringes. Cell count was determined applying automated blood cell counter. The neutrophil adherence was thus determined as a percentage using the formula

$$
\% \text { Neutrophil Adherence }=\frac{N_{u}-N_{t}}{N_{u}} \times 100,
$$

where $N_{u}$ is neutrophil count in untreated blood, $N_{t}$ is neutrophil count of fiber treated blood $[9,18]$.

\section{Determination of delayed-type hypersensitivity (DTH) response}

The mice of group I-VII were sensitized to antigen by injecting SRBC $\left(0.5 \times 10^{9}\right.$ cells $/ \mathrm{mL} / 100 \mathrm{~g}$ suspended in saline solution, i.v.) and after 5 days they were antigenically challenged by injecting SRBC $\left(10^{8}\right.$ cells $\left./ 20 \mu \mathrm{l}\right)$ into sub-planter region of hind paw. Increase in the thickness of paw was measured $24 \mathrm{~h}$ later with digital Vernier caliper and cell-mediated immunity expressed as difference in paw thickness [5,9].

\section{Assessment of humoral immune function}

\section{Serum antibody titre}

After studying cell-mediated immune response, mice were lightly anesthetized with ether on $7^{\text {th }}$ day and blood was withdrawn from the retro-orbital plexus. The serum was separated by centrifuging the blood at $3000 \mathrm{~g}$. Serial two-fold dilution of serum was made in $25 \mu \mathrm{l}$ of saline in 96-well microtitre plate and mixed with $1 \%$ of SRBC $\left(0.025 \times 10^{9}\right.$ cells $)$ in saline. After mixing, plate was kept at room temperature for $2 \mathrm{~h}$. The value of antibody titre was assigned to the highest serum dilution showing visible hemagglutination [10-19].

\section{Result}

\section{Determination of effect of agomelatine on neutrophil adhesion test}

Incubation of blood with nylon fibres produced a decrease in the neutrophil counts due to adhesion of neutrophils to the fibers at a dose of $60 \mathrm{mg} / \mathrm{kg}$ of Melatonin and at a dose of $25 \mathrm{mg} / \mathrm{kg}$ of Agomelatine. There was also a rise in neutrophil count of untreated blood of all treated animals (Tab. 1).

Ta b l e 1

Effect of Agomelatine on Neutrophil Adhesion Test

\begin{tabular}{|c|c|c|c|c|}
\hline \multirow{2}{*}{ No. } & \multirow{2}{*}{ Groups } & \multicolumn{2}{|c|}{ Neutrophil Index } & \multirow{2}{*}{ \% Neutrophil Adhesion } \\
\cline { 2 - 4 } & & UTB & FTB & $17.98 \pm 1.19$ \\
\hline 1 & Control & $1.6 \pm 0.21$ & $1.3 \pm 0.16$ & $57.97 \pm 8.45^{\mathrm{a}}$ \\
\hline 2 & MLT $60 \mathrm{mg} / \mathrm{kg}$ & $7.4 \pm 0.95$ & $2.8 \pm 0.08$ & $48.73 \pm 7.6^{\mathrm{b}}$ \\
\hline 3 & AGO $25 \mathrm{mg} / \mathrm{kg}$ & $5.2 \pm 2.5$ & $2.62 \pm 0.5$ & with control animals, ${ }^{\mathrm{a}} p<0.01 ;$ Melatonin, ${ }^{\mathrm{b}} p<0.05 ;$ Agomelatine $^{2}$ \\
\hline
\end{tabular}




\section{Determination of effect of agomelatine on humoral immune function}

In hemagglutination titre doses of Melatonin 20,40, and $60 \mathrm{mg} / \mathrm{kg}$ showed titre values of $972.8 \pm 307.2$, $1075 \pm 399.9$ and $1638 \pm 250.8$, and doses of agomelatine 1,5 , and $25 \mathrm{mg} / \mathrm{kg}$ showed titre values of $486.4 \pm 153.6,512 \pm 140.2$, and $1280 \pm 256$, respectively, while the titre values of control (Group I) was $277.3 \pm 51.38$, thus demonstrating increase in the titre values of all treated groups (Table 2).

Table 2

Effect of Agomelatine on Humoral Immune Function

\begin{tabular}{|c|c|c|}
\hline No. & Groups & Titre Value \\
\hline 1 & Control & $277.3 \pm 51.38$ \\
\hline 2 & MLT $60 \mathrm{mg} / \mathrm{kg}$ & $1638 \pm 250.8^{\mathrm{a}}$ \\
\hline 3 & AGO $25 \mathrm{mg} / \mathrm{kg}$ & $1280 \pm 256.0^{\mathrm{b}}$ \\
\hline Data represents mean \pm SEM; $(n=5)$, values are compared with control animals, ${ }^{\mathrm{a}} p<0.01 ;$ Melatonin, ${ }^{\mathrm{b}} p<0.05 ;$ agomelatine \\
\hline
\end{tabular}

\section{Determination of agomelatine effect on hematological parameters}

\section{Differential leucocyte count}

The percentage of peripheral blood neutrophils was significantly increased at doses of Mlt 20, 40, and $60 \mathrm{mg} / \mathrm{kg}$ and Ago 1, 5, and $25 \mathrm{mg} / \mathrm{kg}$. On the other hand, the percentage of circulating peripheral blood lymphocytes was considerably increased at doses of Mlt 20,40, and $60 \mathrm{mg} / \mathrm{kg}$ and decreased at doses of Ago 1,5 , and $25 \mathrm{mg} / \mathrm{kg}$. No significant changes in other parameters were seen in all indicated doses (Table 3 ).

Table 3

Effect of agomelatine on DLC

\begin{tabular}{|c|c|c|c|c|c|c|}
\hline \multirow{2}{*}{ No. } & \multirow{2}{*}{ Groups } & $\begin{array}{c}\text { Neutrophils } \\
(\%)\end{array}$ & $\begin{array}{c}\text { Eosinophils } \\
(\%)\end{array}$ & $\begin{array}{c}\text { Basophils } \\
(\%)\end{array}$ & $\begin{array}{c}\text { Lymphocytes } \\
(\%)\end{array}$ & $\begin{array}{c}\text { Monocytes } \\
(\%)\end{array}$ \\
\cline { 3 - 7 } & Control & $28.80 \pm 0.58$ & $2.6 \pm 0.67$ & 0.0 & $65.80 \pm 1.42$ & $0.60 \pm 0.4$ \\
\hline 1 & Mlt $20 \mathrm{mg} / \mathrm{kg}$ & $30.40 \pm 0.51$ & $2.6 \pm 0.40$ & 0.0 & $66.40 \pm 1.36$ & $0.20 \pm 0.20$ \\
\hline 3 & Mlt $40 \mathrm{mg} / \mathrm{kg}$ & $31.60 \pm 1.07$ & $0.2 \pm 0.44$ & 0.0 & $68.80 \pm 1.02$ & $0.0 \pm 0.0$ \\
\hline 4 & Mlt $60 \mathrm{mg} / \mathrm{kg}$ & $32.80 \pm 0.86^{\mathrm{a}}$ & $1.2 \pm 0.37$ & 0.0 & $69.80 \pm 0.37$ & $0.40 \pm 0.24$ \\
\hline 5 & Ago $1 \mathrm{mg} / \mathrm{kg}$ & $29.80 \pm 0.86$ & $2.8 \pm 0.37$ & 0.0 & $67.40 \pm 1.24$ & $0.20 \pm 0.20$ \\
\hline 6 & Ago $5 \mathrm{mg} / \mathrm{kg}$ & $31.60 \pm 1.03$ & $0.2 \pm 0.31$ & 0.0 & $68.60 \pm 1.50$ & $0.20 \pm 0.20$ \\
\hline 7 & Ago $25 \mathrm{mg} / \mathrm{kg}$ & $32.60 \pm 0.81^{\mathrm{b}}$ & $1.2 \pm 0.60$ & 0.0 & $69.20 \pm 0.58$ & $0.20 \pm 0.20$ \\
\hline \multicolumn{7}{|l|}{ Data represents mean \pm SEM; $(n=5)$, values are compared with control animals, ${ }^{\mathrm{a}} p<0.05 ;$ Melatonin, ${ }^{\text {b } p<0.05 ; \text { agomelatine }}$} \\
\hline
\end{tabular}

\section{RBC Count, WBC Count and Haemoglobin content}

Administration of agomelatine was found to increase the total $\mathrm{RBC}$ count $(p<0.01)$ at a dose of $25 \mathrm{mg} / \mathrm{kg}$, but the same was unaffected at lower doses of 1 and $5 \mathrm{mg} / \mathrm{kg}$. There was no considerable change in the $\mathrm{Hb}$ content at all three doses, whereas total WBC count illustrated a rise $(p<0.05)$ at $25 \mathrm{mg} / \mathrm{kg} \mathrm{dose}$ (Table 4).

Effect of agomelatine on RBC Count, WBC Count and Haemoglobin content

\begin{tabular}{|c|c|c|c|c|}
\hline \multirow{2}{*}{ No. } & \multirow{2}{*}{ Groups } & \multicolumn{3}{|c|}{ Parameters } \\
\hline & & RBC Count $\left(10^{12} / \mathrm{L}\right)$ & WBC Count $\left(10^{12} / \mathrm{L}\right)$ & $\mathrm{Hb}(\%)$ \\
\hline 1 & Control & $8.60 \pm 0.33$ & $6.02 \pm 1.0$ & $13.38 \pm 0.40$ \\
\hline 2 & Mlt $20 \mathrm{mg} / \mathrm{kg}$ & $9.20 \pm 0.17$ & $8.20 \pm 8.5$ & $15.76 \pm 0.71$ \\
\hline 3 & Mlt $40 \mathrm{mg} / \mathrm{kg}$ & $10.04 \pm 0.67$ & $9.18 \pm 9.7$ & $16.06 \pm 0.41$ \\
\hline 4 & Mlt $60 \mathrm{mg} / \mathrm{kg}$ & $11.15 \pm 0.64^{\mathrm{a}}$ & $10.08 \pm 5.8^{\mathrm{b}}$ & $17.70 \pm 0.60^{\mathrm{a}}$ \\
\hline 5 & Ago $1 \mathrm{mg} / \mathrm{kg}$ & $8.61 \pm 0.98$ & $6.08 \pm 9.7$ & $13.56 \pm 0.41$ \\
\hline 6 & Ago $5 \mathrm{mg} / \mathrm{kg}$ & $9.13 \pm 0.42$ & $6.1 \pm 9.2$ & $13.04 \pm 1.07$ \\
\hline 7 & Ago $25 \mathrm{mg} / \mathrm{kg}$ & $11.10 \pm 0.64^{\mathrm{a}}$ & $9.8 \pm 5.6^{\mathrm{b}}$ & $15.82 \pm 0.79^{\mathrm{ns}}$ \\
\hline
\end{tabular}


Determination of agomelatine effect on delayed type hypersensitivity response

Melatonin $(60 \mathrm{mg} / \mathrm{kg})$ and agomelatine $(25 \mathrm{mg} / \mathrm{kg})$ produced a significant, dose-related increase in DTH reactivity of mice. The edema achieved a peak at $48 \mathrm{~h}$ comparing to control at $48 \mathrm{~h}$ (Table 5).

Table 5

Effect of agomelatine on delayed type hypersensitivity response

\begin{tabular}{|c|c|c|c|c|c|}
\hline \multirow{2}{*}{ No. } & \multirow{2}{*}{ Groups } & \multicolumn{4}{|c|}{ Paw difference (mm) } \\
\hline & & $0 \mathrm{hr}$ & $2 \mathrm{hr}$ & $24 \mathrm{hr}$ & $48 \mathrm{hr}$ \\
\hline 1 & Control & $0.89 \pm 0.18$ & $1.59 \pm 0.15$ & $1.79 \pm 0.14$ & $2.58 \pm 0.20$ \\
\hline 2 & Mlt $20 \mathrm{mg} / \mathrm{kg}$ & $0.96 \pm 0.24$ & $1.80 \pm 0.22$ & $2.00 \pm 0.19$ & $2.78 \pm 0.33$ \\
\hline 3 & Mlt $40 \mathrm{mg} / \mathrm{kg}$ & $1.30 \pm 0.13$ & $1.84 \pm 0.06$ & $2.04 \pm 0.10$ & $2.95 \pm 0.43^{\mathrm{a}}$ \\
\hline 4 & Mlt $60 \mathrm{mg} / \mathrm{kg}$ & $1.53 \pm 0.34$ & $2.50 \pm 0.11$ & $2.61 \pm 0.10$ & $3.53 \pm 0.47^{b}$ \\
\hline 5 & Ago $1 \mathrm{mg} / \mathrm{kg}$ & $0.89 \pm 0.18$ & $1.59 \pm 0.15$ & $1.79 \pm 0.14$ & $2.85 \pm 0.19$ \\
\hline 6 & Ago $5 \mathrm{mg} / \mathrm{kg}$ & $1.30 \pm 0.28$ & $2.00 \pm 0.26$ & $2.21 \pm 0.22$ & $3.03 \pm 0.19^{c}$ \\
\hline 7 & Ago $25 \mathrm{mg} / \mathrm{kg}$ & $1.08 \pm 0.31$ & $2.37 \pm 0.18$ & $2.60 \pm 0.20$ & $3.05 \pm 0.12^{b}$ \\
\hline
\end{tabular}

\section{Discussion}

Essentially, agomelatine has been determined as the antidepressant drug for laboratory animals. In this study, agomelatine showed an overall stimulatory effect on the specific and non-specific immune functions of mice. Stimulatory effects were observed at $25 \mathrm{mg} / \mathrm{kg}$. Drug at this dose increased cell counts indicating its stimulatory effect on hematopoietic cells. Overall, it was concluded that $25 \mathrm{mg} / \mathrm{kg}$ is the optimum dose for mice. Thus, $25 \mathrm{mg} / \mathrm{kg}$ dose of Agomelatine seems to be pharmacologically effective dose for mouse as far as immunomodulatory effects are concerned. The response at lower dose i. e. $1 \mathrm{mg} / \mathrm{kg}$, was either identical to control group animals or mildly stimulated comparing to control animals.

Immune activation is an effective and protective approach for treating infectious diseases. Among the leukocytes, only antigen specific lymphocytes possessed the diversity, specificity, memory, and self-recognition indicating an adaptive immune response. It was observed that agomelatine caused significant increase in TLC and lymphocyte population designating the presence of its immunological effects.

Boundary of neutrophil from the blood stream requires a firm adhesion which is mediated through the interaction of the $\beta_{2}$ integrins present on the neutrophil. The $\beta_{2}$ integrins stored in the cell granules and upregulated for a firm adhesion. In this study, adherence of neutrophil to the nylon fiber was increased in the treated group comparing to the control.

DTH is a part of the process of immunity causing many intercellular infections, microorganisms, especially chronic diseases as tuberculosis. DTH requires the specific recognition of a given antigen by activated $\mathrm{T}$ lymphocytes, which subsequently proliferate and release cytokines. These, in turn, increase vascular permeability, induce vasodilation, macrophage accumulation and activation, promoting increased phagocytic activity and concentration of lytic enzymes for more effective killing. In the present study, SRBC was used to elicit hypersensitivity reaction of mice. It was found that agomelatine potentiated the DTH reaction induced by SRBC at $10^{8}$ cells. Increase in DTH reaction of mice in response to thymus-dependent antigen revealed the stimulatory effect of agomelatine on $\mathrm{T}$ lymphocytes and accessory cell types for the expression of reaction.

The humoral immunity involves interaction of B cells with the antigen and their subsequent proliferation and differentiation into antibody-secreting plasma cells. Antibody functions as the effector of the humoral response by binding to antigen and neutralizing it or facilitating its elimination by cross-linking to form clusters that are ingested by phagocytic cells. To evaluate the effect of Agomelatine on humoral response, its influence was tested on sheep erythrocyte specific hemagglutination antibody titre in mice. It was found that agomelatine enhances the production of circulating antibody titre. This indicates the enhanced responsiveness of macrophages and $\mathrm{T}$ and $\mathrm{B}$ lymphocytes subsets involved in antibody synthesis.

\section{Conclusions}

Reviewing all the data presently available on agomelatine, a stimulatory effect was noted. This stimulatory effect is associated with increased cytokine production, enhanced phagocytosis and increased natural 
killer cell activity. The results of this study propose that agomelatine may stimulate both the cellular and humoral immunity. Further investigation is suggested for the precise mechanism of action for the stimulatory effect of the drug. Effects were evaluated at different doses of 1,5, and $25 \mathrm{mg} / \mathrm{kg}$ using various parameters as an effect on hematological parameters. The results were further utilized to evaluate the activity on the cellular and humoral branches of immunity. Its reported immunomodulatory effects deserve further investigation for its use in the cases of clinical immunostimulation. The drug can be evaluated for its consequence on stress induced immunomodulation.

\section{References}

1 Ettaoussi M. Design, synthesis and pharmacological evaluation of new series of naphthelenic analogues as melatoninergic (MT1 and MT2) and serotoninergic 5HT2C dual ligands / M. Ettaoussi // Eur. J. Med. Chem. - 2012. - P. 1-14.

2 Kennedy S.H. Agomelatine and its therapeutic potential in the depressed patient / S.H. Kennedy, B.S. Eisfeld // Neuropsychiatr Dis and Treat. - 2007. - Vol. 3 (4). - P. 423-428.

3 Kindt T.J. Kuby Immunology / T.J. Kindt, R.A. Goldsky, B.A. Osborne. — New York: W.H. Freeman, 2007. — P. 31-36.

4 Norman T.R. Agomelatine suppresses locomotor hyperactivity in olfactory bulbectomised rats: A comparison to melatonin and to the 5HT2c antagonist / T.R. Norman // Eur. J. Pharmacol. — 2012. - P. $27-32$.

5 Howland R.H. Critical appraisal and update on the clinical utility of agomelatine, a melatonergic agonist, for the treatment of major depressive disease in adults / R.H. Howland // Neuropsychiatr Dis and Treat. — 2009. — Vol. 5. — P. 563-576.

6 Siopes T.D. Diurnal variation in the cellular and humoral immune responses of Japanese quail: Role of melatonin / T.D. Siopes, H.A. Underwood // General and Comparative Endocrinology. — 2008. — P. 245-249.

7 Ghule B.V. Immunostimulant effects of Capparis zeylanica Leaves / B.V. Ghule, G. Murugananthan, P.D. Nakhat, P.G. Yeole // J. Ethnopharmacol. — 2006. - P. 311-315.

8 Hafeez B.B. Immunomodulatory effect of fenugreek (Trigonella foenum graecum L.) extract in mice / B.B. Hafeez, R. Haque, S. Parvez, S. Pandey, S. Raisuddin // Int. Immunopharmacol. - 2003. - Vol. 3. — P. 257-265.

9 Umathe S.N. Leuprolide - a GnRH agonist prevents restraint stress-induced immunosupression via sex steroid-independent peripheral mechanism in mice / S.N. Umathe, P.V. Dixit, M.M. Wanjari, M.P. Ullewar // Int. Immunopharmacol. — 2008. — Vol. 8. - P. 71-79.

10 Amer S. Immunostimulating effects of sugar cane extract on x-ray radiation induced immunosuppression in the chicken / S. Amer, K. Jeong, M. Abasy, M. Motobu, Y. Koyama, K. Koge, Y. Hirota // Int. Immunopharmacol. — 2004. — Vol. 4. — P. $71-$ 77.

11 Claustart B. The basic physiology and pathophysiology of melatonin / B. Claustart, J. Bruno, G. Chazot // Sleep Medicine Reviews. - 2005. - Vol. 9. - P. 11-24.

12 Esquafino A.I. Circadian organization of the immune response: A role for melatonin / A.I. Esquafino, S.R. Perumal-Pandis, D.P. Cardinali // Clin and Applied Immunol. - 2004. - Vol. 4. - P. 423-433.

13 Fararjeh M. Evaluation of immunosuppression induced by metronidazole in Balb/c mice and human peripheral blood lymphocytes / M. Fararjeh, K.M. Mohammad, Y. Bustanji, H. Alkhatib, S. Abdalla // Int. Immunopharmacol. — 2008. — Vol. 8. — P. 341-350.

14 Gokhale A. Investigations into the immunomodulatory activity of Argyreia speciosa / A. Gokhale, D. Saraf // J. Ethnopharmacol. - 2003. - P. 109-114.

15 Pfister R.R. The effect of citrate on the adherence of neutrophils to nylon fibers in vitro / R.R. Pfister, J.L. Haddox, T.L. Synder // Invest Opthalmol \& Vis Sci. — 1998. — Vol. 29. — P. 869-875.

16 Smith W.C. Cooperative interactions of LFA-1 and Mac-1 intercellular adhesion molecule-1 in facilitating adherencre and transendothilial migration of human neutrophils in vitro / W.C. Smith, D.S. Marlin, R. Rothlein, C. Toman, C.D. Anderson // J. Clin. invst. - 1989. - Vol. 83. - P. 2008-2017.

17 Springer A.T. Traffic signals on endothelium for lymphocytes reticulation and leukocyte emigration / A.T. Springer // Annual Review of Physiology. — 1995. — Vol. 57. - P. 827-872.

18 Terron M.P. Effect of melatonin and tryptophan on humoral immunity in young and old ringdoves (Streptopelia risoria) / M.P. Terron, J. Delgado Parde, C. Barriga, R.J. Reiter, A.B. Rodriguez // Experimental Gerontology. — 2009. - P. $653-658$.

19 Vikstrom E. Components with potential immunosuppressive activity in lipopolysaccharide of laboratory Pseudomonas aeruginosa strains / E. Vikstrom // Immunology letters. — 2003. — P. 29-33. 


\title{
Вайшали Д. Нафаде, Гаураф Парихар, Д.К. Джаин, Атул Р. Бендале \\ Тышқандардағы агомелатиннің жасушалық және гуморальдық иммунитетке әсерін зерттеу
}

\begin{abstract}
Агомелатин алғаш рет зертханалық жануарларда антидепрессант ретінде сипатталған. Осы зерттеуде агомелатин тышқандардағы нақты, сондай-ақ спецификалық емес иммундық функцияларға жалпы қоздырушы әсерін көрсетті. Агомелатинді адамға енгізу қарапайым, өйткені ол дәрілік түр түрінде оңай қолжетімді. Оның жалпы иммуномодуляциялық әсері клиникалық иммунокүшейту жағдайында қолдану үшін одан әрі зерттеуді қажет етеді. Алынған нәтижелерді агомелатин жасушалық және гуморальды иммунитетті қоздыруы мүмкін деп болжанған. Препараттың қоздырушы әсері үшін нақты әсер ету механизмін түсінуге қосымша эксперименттер қажет. Әсерлер гематологиялық параметрлерге әсер ету сияқты әртүрлі параметрлерді қолдана отырып, 1,5 және 25 мг/кг әртүрлі дозаларда бағаланды. Нәтижелер иммунитеттің жасушалық және гуморальды тармақтарындағы белсенділікті бағалау үшін қосымша қолданылды.
\end{abstract}

Кілт сөздер: агомелатин, жасушалық иммунитет, гуморальдық иммунитет, иммунокүшейту, антидепрессант, гематология, антагонист 5ht2, нейтрофилдердің адгезиясына тест.

\section{Вайшали Д. Нафаде, Гаураф Парихар, Д.К. Джаин, Атул Р. Бендале \\ Исследование влияния агомелатина на клеточный и гуморальный иммунитет у мышей}

\begin{abstract}
Агомелатин впервые был описан как антидепрессант у лабораторных животных. В настоящем исследовании агомелатин показал общее стимулирующее действие на специфические и неспецифические иммунные функции у мышей. Стимулирующие эффекты наблюдались при дозе 25 мг/кг. Введение агомелатина человеку является простым, поскольку он доступен в виде лекарственной формы. Его общие иммуномодулирующие эффекты требуют дальнейшего изучения для использования в случаях клинической иммуностимуляции. Полученные результаты позволяют предположить, что агомелатин может стимулировать как клеточный, так и гуморальный иммунитет. Необходимы дальнейшие эксперименты, чтобы понять точный механизм действия для стимулирующего эффекта препарата. Эффекты оценивали при различных дозах 1, 5 и 25 мг/кг с использованием различных параметров, таких как влияние на гематологические параметры. Результаты были дополнительно применены при оценке активности на клеточных и гуморальных ветвях иммунитета.
\end{abstract}

Ключевые слова: агомелатин, клеточный иммунитет, гуморальный иммунитет, иммуностимуляция, антидепрессант, гематология, антагонист 5НТ2, тест на адгезию нейтрофилов.

\section{References}

1 Ettaoussi, M. (2012). Design, synthesis and pharmacological evaluation of new series of naphthelenic analogues as melatoninergic (MT1 and MT2) and serotoninergic 5HT2C dual ligands. Eur J Med Chem, 1-14.

2 Kennedy, S.H., \& Eisfeld, B.S. (2007). Agomelatine and its therapeutic potential in the depressed patient. Neuropsychiatr Dis and Treat, 3 (4), 423-428.

3 Kindt, T.J., Goldsky, R.A., \& Osborne, B.A. (2007). Kuby Immunology. New York: W.H. Freeman, 31-36.

4 Norman, T.R. (2012). Agomelatine suppresses locomotor hyperactivity in olfactory bulbectomised rats: A comparison to melatonin and to the 5HT2c antagonist. Eur J Pharmacol, 27-32.

5 Howland, R.H. (2009). Critical appraisal and update on the clinical utility of agomelatine, a melatonergic agonist, for the treatment of major depressive disease in adults. Neuropsychiatr Dis and Treat, 5, 563-576.

6 Siopes, T.D. \& Underwood, H.A. (2008). Diurnal variation in the cellular and humoral immune responses of Japanese quail: Role of melatonin. General and Comparative Endocrinology, 245-249.

7 Ghule, B.V., Murugananthan, G., Nakhat, P.D., \& Yeole, P.G. (2006). Immunostimulant effects of Capparis zeylanica Leaves. J Ethnopharmacol, 311-315.

8 Hafeez, B.B., Haque, R., Parvez, S., Pandey, S., \& Raisuddin, S. (2003). Immunomodulatory effect of fenugreek (Trigonella foenum graecum L.) extract in mice. Int. Immunopharmacol, 3, 257-265.

9 Umathe, S.N., Dixit, P.V., Wanjari, M.M., \& Ullewar, M.P. (2008). Leuprolide -a GnRH agonist prevents restraint stressinduced immunosupression via sex steroid-independent peripheral mechanism in mice. Int Immunopharmacol., 8, 71-79.

10 Amer, S., Jeong, K., Abasy, M., Motobu, M., Koyama, Y., Koge, K., \& Hirota, Y. (2004). Immunostimulating effects of sugar cane extract on x-ray radiation induced immunosuppression in the chicken. Int Immunopharmacol., 4, 71-77. 
11 Claustart, B., Bruno, J., \& Chazot, G. (2005). The basic physiology and pathophysiology of melatonin. Sleep Medicine Reviews, 9, 11-24.

12 Esquafino, A.I., Perumal-Pandis, S.R., \& Cardinali, D.P. (2004). Circadian organization of the immune response: A role for melatonin. Clin and Applied Immunol., 4, 423-433.

13 Fararjeh, M., Mohammad, K.M., Bustanji, Y., Alkhatib, H., \& Abdalla, S. (2008). Evaluation of immunosuppression induced by metronidazole in Balb/c mice and human peripheral blood lymphocytes. Int Immunopharmacol., 8, 341-350.

14 Gokhale, A., \& Saraf, D. (2003). Investigations into the immunomodulatory activity of Argyreia speciosa. J Ethnopharmacol., 109-114.

15 Pfister, R.R., Haddox, J.L., \& Synder, T.L. (1988). The effect of citrate on the adherence of neutrophils to nylon fibers in vitro. Invest Opthalmol \& Vis Sci., 29, 869-875.

16 Smith, W.C., Marlin, D.S., Rothlein, R., Toman, C., \& Anderson, C.D. (1989). Cooperative interactions of LFA-1 and Mac-1 intercellular adhesion molecule-1 in facilitating adherencre and transendothilial migration of human neutrophils in vitro. $J$ Clin invst., 83, 2008-2017.

17 Springer, A.T. (1995). Traffic signals on endothelium for lymphocytes reticulation and leukocyte emigration. Annual Review of Physiology, 57, 827-872.

18 Terron, M.P., Delgado, J. Parde, Barriga, C, Reiter, R.J., \& Rodriguez, A.B. (2009). Effect of melatonin and tryptophan on humoral immunity in young and old ringdoves (Streptopelia risoria). Experimental Gerontology, 653-658.

19 Vikstrom, E. (2003). Components with potential immunosuppressive activity in lipopolysaccharide of laboratory Pseudomonas aeruginosa strains. Immunology letters, 29-33. 